\title{
Insights gained from genomic studies on the role of sex steroids in the aetiology of endometriosis
}

\author{
Philippa TK Saunders ${ }^{1 *}$ \\ ${ }^{1}$ Centre for Inflammation Research, The University of Edinburgh, 47 Little France Crescent, \\ Edinburgh Bioquarter, Edinburgh EH16 4TJ \\ 11p.saunders@ed.ac.uk \\ *Correspondence
}

\begin{abstract}
Endometriosis is a chronic neuro-inflammatory disorder the defining feature of which is the growth of tissue (lesions) that resembles the endometrium in sites outside the uterus. Estimates of prevalence typically quote rates of $\sim 10 \%$ of women of reproductive age, equating to $\sim 190$ million women world-wide. Three subtypes of endometriosis are usually considered when discussing the aetiology of the disorder - superficial peritoneal, ovarian (endometrioma cysts), and deep (infiltrating). Genetic, hormonal and immunological factors have all been proposed as contributing to risk factors associated with the development of lesions. Twin studies report the heritable component of endometriosis as $\sim 50 \%$. Genome wide association studies (GWAS) have been conducted allowing unbiased scanning of the genome for single nucleotide polymorphisms (SNPs) in many thousands of individuals. These studies have identified SNPs that appear over-represented in patients with endometriosis, particularly those with more extensive disease (stage III/IV). Amongst the larger scale GWAS there has been replication of SNPs near genes involved in oestrogen and other signalling pathways including ESR1 (oestrogen receptor alpha), GREB1, HOXA10, WNT4 and MAPK kinase signalling. The results from patients with endometriosis have also provided an opportunity to make comparisons with GWAS conducted on other patient cohorts including those with reproductive traits (age at menarche) and disorders (fibroids, endometrial and ovarian cancer) and conditions that are reported by women with endometriosis (migraine, depression). These comparative studies have highlighted some shared genetically-controlled biological mechanisms, including hormone-regulated pathways which might explain the co-occurrence of endometriosis with these disorders.

In summary, unbiased genetic analysis has provided new insights into the genetic factors that may contribute to increased risk of developing endometriosis. New studies are needed to broaden the range of patients contributing to these datasets and to improve integration with non-genomic and tissue expression data before their full potential for diagnosis and improvements in patient care can be fully realised.
\end{abstract}

Keywords: genome wide association studies (GWAS); single nucleotide polymorphism (SNP); oestrogen, ESR1, HOXA10. 


\section{Introduction to endometriosis}

Endometriosis is a chronic incurable disorder the hallmark of which is growth of tissue 'lesions' that have histological features resembling endometrium outside the uterine cavity (Horne and Saunders, 2019; Zondervan et al., 2020). Estimates of prevalence typically quote rates of $\sim 10 \%$ of women of reproductive age, equating to 190 million women world-wide (Zondervan et al., 2020). This is likely to be an underestimate as many women, or those assigned as female at birth, may remain undiagnosed and 'lesions' have also been found in asymptomatic fertile women (Shafrir et al., 2018). Prevalence rates may be as high as $50 \%$ in women seeking treatment for infertility (Meuleman et al., 2009): rates in adolescents with pelvic pain range from $49-75 \%$ (Shafrir et al., 2018). A recent review highlighted the profound negative impact on the lives of individuals with the disorder (Missmer et al., 2021).

Endometriosis lesions are most commonly found within the pelvic cavity (Figure 1, (Zondervan et al., 2020)) but may also occur in other sites including the thorax and nervous system (Andres et al., 2020). Superficial peritoneal lesions (SPE) are located at different sites on the peritoneal wall (e.g. ovarian fossa, uterosacral ligaments, Pouch of Douglas) and are often recorded as having various colours, ranging from yellow to black. Pelvic lesions can also occur as cysts on the ovary (endometrioma) and as nodules which invade the wall of organs including the bowel (deep, DE) (Zondervan et al., 2020). The location, type, degree of invasion, extent of disease and associated adhesions has been used to 'stage' the disease with the most widely adopted scheme being that proposed by the American Society of Reproductive Medicine (ASRM) (1997). This scheme proposes classification of endometriosis lesions into four stages I to IV: stage I - mild, stage II - minimal, stage III - moderate, stage IV - severe. The assignment of stage is based on visual analysis at time of surgery and a points based system with the majority of peritoneal disease scored as stage I/II and more extensive disease associated with adhesions and deep nodules as stage III or IV (1997).

Endometriosis is associated with a wide range of symptoms including pelvic pain (which may be more severe during menstruation), painful sex, heavy menstrual bleeding, bladder and bowel symptoms as well as those shared with other chronic pain conditions such as fatigue and depression. Several reports have recorded poor correlation between patient reported pain and endometriosis stage (Vercellini et al., 2007). Some commentators have suggested endometriosis should be considered a syndrome with greater emphasis on symptoms rather than lesion subtype/location (Saunders and Horne, 2021). In addition, results from genomic and other studies (discussed below) suggest there may be differences in the aetiology of deep and ovarian disease compared with peritoneal, superficial lesions.

Definitive diagnosis of endometriosis usually relies upon a surgical laparoscopy although imaging using transvaginal ultrasound or MRI can be helpful in cases of ovarian or deep disease (Horne and Saunders, 2019). To date, progress towards validation of biomarkers that could form the basis of a robust reproducible blood test has been slow (Rizner, 2014). Delays in diagnosis are compounded by the variety of symptoms experienced by women with endometriosis that can be confused with conditions such as irritable bowel syndrome and bladder pain syndrome.

In this review, I will consider the evidence that genetic changes in key gene pathways may contribute to the risk of endometriosis, the insights that genomics have given us into the role(s) of sex steroids in the aetiology of the disease and genetic associations with other disorders. Opportunities to use the information to improve non-surgical diagnosis or personalised therapies will be discussed. 


\section{Why is endometriosis usually referred to as a 'hormone-dependent disorder'?}

Endometriosis only occurs spontaneously in menstruating species including women and some primates. Explanations for the formation of endometriosis lesions, particularly those in the pelvis, have largely focused on a theory first proposed in the 1920's that tissue fragments including stem/progenitor cells and immune cells transferred via Fallopian tubes at time of menstruation (retrograde flow) survive and become attached to the peritoneal wall and other sites (Horne and Saunders, 2019; Zondervan et al., 2020). Other theories include transfer via the vasculature and (Yovich et al., 2020) and coelomic metaplasia (Zondervan et al., 2020).

The human endometrium is a complex multicellular tissue that is exquisitely sensitive to the actions of sex steroids with cycles of proliferation, differentiation breakdown, shedding and repair orchestrated by changes in circulating concentrations of endocrine hormones secreted by the ovaries (Critchley et al., 2020; Gibson et al., 2020). The action of steroids, including oestrogens, progestins and androgens is mediated by receptors notably those encoded by genes (ESR1, ESR2, PR, AR) that are members of a large family of ligand-activated transcription factors (Mangelsdorf et al., 1995). Detailed evaluation of cell specific patterns of immunoexpression of oestrogen receptors alpha (ESR1) and beta (ESR2)(Critchley et al., 2001; Critchley et al., 2002), progesterone receptor subtypes (PRA, PRB) (Gellersen and Brosens, 2003; Wang et al., 1998) and androgen receptors (Gibson et al., 2020) have been conducted. These studies combined with evidence from cell-based assays and mouse models has highlighted a key role for ESR1 in regulation of endometrial cell proliferation and stromalepithelial cell signalling (Winuthayanon et al., 2010; Winuthayanon et al., 2017). Progesterone acting via PR, in combination with other factors including cAMP, plays a critical role in the differentiation (decidualization) of endometrial stromal fibroblasts resulting in remodelling of their cytoskeleton (shape), changes in gene expression and a novel secretory profile (Gellersen and Brosens, 2003). Decidualization is a dynamic time-dependent process that starts in cells close to the vasculature: efficient decidualization is essential for establishment of a viable pregnancy (Gellersen and Brosens, 2014). In vitro models of decidualization have revealed an increase in expression of steroid metabolising enzymes including those encoded by CYP19 (aromatase, (Gibson et al., 2013), AKR1C3 (Gibson et al., 2016) and members of the 11beta and 17 beta hydroxsteroid enzyme families (Aghajanova et al., 2009). Decidualization is also associated with increased synthesis and secretion of factors such as interleukin 15 (Dunn et al., 2002) that regulate recruitment of immune cells including the CD56+ uterine natural killer cells (uNK) which play a critical roles in establishment of pregnancy including clearance of senescent decidual cells (Brighton et al., 2017) and remodeling of the vasculature (Gibson et al., 2015). Menstrual shedding no longer occurs after menopause when steroid secreting ovarian follicles and corpora lutea are no longer formed.

Studies on the role of steroids in the aetiology and pathogenesis of endometriosis have included evidence of changes in the function of the endometrium in women with endometriosis, measurement of steroids in the peritoneal fluid and detailed analysis of expression of steroid receptors, metabolising enzymes and steroid concentrations in the lesions themselves (Figure 1). The results of these studies have consistently reported differences between samples from women with or without endometriosis and some of the key papers are summarized in Table 1. Studies that have been particularly influential within the field of endometriosis research have been those that have identified altered responses to progesterone ('progesterone resistance', (Burney et al., 2007)) which have implications for the use of drugs which target the progesterone receptor as treatments for endometriosis patients (Reis et al., 2020). There is also a strong body of work which has identified changes in expression of enzymes and the creation 
of an oestrogen-dominated microenvironment within the lesions (Dassen et al., 2007) which has provided the rationale for the use of enzyme inhibitors, including those targeting the aromatase enzyme, as therapeutics (Dunselman et al., 2014).

Readers interested in a learning more about the many studies using human cells and tissues to exploring the role of steroid receptors in endometriosis are encouraged to read the expert review by Yilmaz and Bulun which summarises papers published up to 2018 (Yilmaz and Bulun, 2019).

\section{Methodology}

On 06/01/2021 searches were conducted on PUBMED and SCOPUS using the following terms endometriosis+genetics (Pubmed 3488 publications, Scopus 1676); endometriosis+genetics+hormone (848 publications); endometriosis+genetics+estrogen (615 publications); endometriosis+genetics+progesterone (352 publications); endometriosis+genetics+androgen (82 publications); endometriosis+genomics (Pubmed 1005 publications, Scopus 98); endometriosis+genomics+hormone (186 publications:; endometriosis+GWAS (106 publications); endometriosis+GWAS+hormone (20 publications); endometrosis+GWAS+estrogen (11 publications); endometriosis+epigenetics (Pubmed 247 publications, Scopus 248); endometriosis+epigenetics+steroid (Pubmed 41 publications, Scopus 30). One conclusion that can be drawn from these unrefined searches was that there is a larger body of work describing the impact/association of estrogen with endometriosis than other steroid hormones.

An additional search was conducted using Pubmed on 11th May 2021 focusing on papers published since 2019 using the search terms endometriosis+GWAS (26 results) and endometriosis+estrogen (310 results) to capture the most recent relevant papers. The Bioarchiv and Medarchiv databases of non-peer reviewed manuscripts were searched on 12th June 2021 to identify any articles published since October 2020.

\section{Evidence that endometriosis is a heritable disease}

Patients often report cases of endometriosis in close relatives. A study using questionaires explored the incidence of endometriosis in female monozygotic and dizygotic twins in the Australian National Health and Medical Research Council Twin Register. More than three thousand twins responded with 215 twins recording a diagnosis of endometriosis; when available medical and pathology reports were included the authors concluded $\sim 51 \%$ of the variance of the latent liability to endometriosis could be due to additive genetic influences (Treloar et al., 1999). In a subsequent study the same group published a key paper based on genetic linkage analysis of 1176 families in Australia and the UK with at least 2 affected individuals (Treloar et al., 2005a). They used a positional-cloning approach that starts with linkage analysis to identify genomic regions likely to harbour genes that contributed to disease predisposition. They identified significant linkage (MLS=3.16) to a novel susceptibility locus on chromosome 10q26. Notably a subsequent GWAS study (described below) identified a number of genetic polymorphisms in this region associated with endometriosis using larger numbers of patient samples (Painter et al., 2011b). A recent study used population data in Korea to quantify the familial risk of endometriosis among full siblings $(19,195$ women with 1,126 cases) to examine interactions between family history, smoking, age at menache and body mass index (Kim et al., 2021). This study endorsed the findings of earlier studies showing increased risk associated with having an affected sibling which was higher in twins. 


\section{Genomic studies on samples from women with and without a diagnosis of endometriosis have identified gene polymorphisms that appear associated with disease risk}

To complement the studies that had identified specific changes in gene expression in lesions and/or endometrium from women with endometriosis (Table 1; reviewed by (Saunders and Horne, 2021; Yilmaz and Bulun, 2019; Zondervan et al., 2020) polymorphisms in individual candidate genes have been investigated (Bedaiwy et al., 2006; Borghese et al., 2008a; Kitawaki et al., 2001; Lee et al., 2007; Treloar et al., 2005b; Wang et al., 2004; Zhao et al., 2008) with a mixture of positive and negative findings. A number of these investigations were focused on examination of polymorphisms in steroid receptor genes. For example, Kitawaki et al examined the distribution of PVUII genotypes (PP, Pp, and pp) in the ESR1(oestrogen receptor alpha) gene using DNA from blood samples (203 women, 109 with a diagnosis of endometriosis) reaching the conclusion that the $\mathrm{Pp} / \mathrm{pp}$ variants were higher in women with endometriosis, fibroids or adenomyosis (Kitawaki et al., 2001). The negative findings in other studies were in part believed to be due to low numbers of patients versus controls something that has now been addressed using genome scanning (genome wide association studies, GWAS) which to look for changes in sequences across the entire genome in an unbiased way. In their 2016 review Zondervan and colleagues highlight the technical developments including the generation of data in the 1000 genomes project and improved statistical analysis that have made GWAS analysis more robust (Zondervan et al., 2016). For complex diseases such as endometriosis large numbers of individuals need to be evaluated, it is also important that the phenotype of patients has been recorded using robust clinical criteria and controls are drawn from populations with similar ancestry. A summary of GWAS conducted on endometriosis patients is given in Table 2 and the results that appear to implicate steroid regulated pathways in the development of the disease are discussed in more detail below.

In their 2011 studies Painter and colleagues identified SNPs on 7p15.2 (Painter et al., 2011a) and 10q26 (Painter et al., 2011b) in regions of the genome that appeared associated with HOXA10 and CYP2C19C. The finding of a SNP associated with HOXA10 was exciting as there was a large body of work that has highlighted the importance of HOX genes in development of the female reproductive tract (Taylor, 2000).

In a follow up study, the authors re-analysed 80 SNPs highlighting rs4244285, a functional SNP in exon 5 of $C Y P 2 C 19$, that abrogates its function through the creation of an alternative splice site and another functional SNP in the CYP2C19 promoter. The authors proposed that variants of CYP2C19 may contribute to endometriosis susceptibility in both familial and sporadic cases. (Painter et al., 2014). CYP2C19 is a member of the cytochrome P450 enzyme superfamily often implicated in drug metabolism by the liver. In the context of endometriosis is notable that this enzyme acts as an expoxygenase that can convert arachidonic acid to four epoxyeicosatrienoic acid (EET) regioisomers which have diverse impacts on blood vessels and inflammation (Spector, 2009). Whilst there is no specific evidence for a role for CYP2C19 in endometrium or endometriosis it is notable that expoxygenase activity has been studied in the context of macrophage activity in wounding and fibrosis both processes relevant to development of endometriosis lesions (Guo, 2018).

A number of primary GWAS and subsequent meta-analyses have reported associations between endometriosis and SNPs near genes involved in signalling pathways implicated in endometrial tissue function (Table 2). For example Nyholt and colleagues (Nyholt et al., 2012) identified rs7521902 at 1p36.12 near WNT4; thereafter the group conducted fine mapping of 1 p36 region spanning WNT4, CDC42 and LINC00339 finding three additional SNPs located in DNA sequences with potential overlap with binding sites for FOXA1, FOXA2, ESR1, and ESR2 (Luong et al., 2013). In their meta-analysis, which incorporated data from eight of the 
GWAS conducted before 2014, Rahmiglou and co-investigators confirmed significance for SNPs associated with WNT4, CREB1 and VEZT. They also highlighted the stronger effect sizes among women diagnosed with more extensive or ovarian disease (Stage III/IV) for 8 of the SNPs (Rahmioglu et al., 2014). Other studies have also reported that the most robust findings are found if results stratified and sorted according to disease stage (Sapkota et al., 2015a).

A meta-analysis with more than 17,000 patients and 191,000 controls identified five novel SNPs associated with steroid signalling pathways as well as five secondary association signals, including two at the ESR1 locus, resulting in 19 independent SNPs which the authors postulated might contribute to $5.19 \%$ of variance in endometriosis (Sapkota et al., 2017). Whilst these studies have revealed some promising leads the population studied has largely been limited to women with European ancestry although the 7p15.2 SNP was also replicated in Japanese women (Nyholt et al., 2012). In a small study Wang et al focused on endometriomas in Han Chinese women finding the most significant signalling pathway was that associated with IGF1 receptor (Wang et al., 2017) which is interesting as macrophage-derived IGF1 has recently been highlighted as a nerve sensing factor in endometriosis-associated pain (Forster et al., 2019).

Replication and meta-analysis of previous GWAS confirmed vezatin as a locus having a strong association with endometriosis in Italian patients (Pagliardini et al., 2015). Vezatin has been shown to play a key role in junctional complexes found in epithelial cells [REF] with evidence of a role in neuromuscular nerve signalling [Koppel et al MBC 2019]. Immunostaining of endometrium suggested the protein was in multiple cell types and not altered according to cycle stage; in the same study the authors focused on the 12q22 region and explored whether the SNPs found in this region that are associated with the VEZT gene (rs10859871) had an impact on expression in endometrial tissue samples (eQTL analysis) (Holdsworth-Carson et al., 2016). A total of 11 coding variants of VEZT (including one novel variant) were identified from an endometriosis cohort consisting of 2594 cases and 4496 controls) but they did not find any definitive evidence of a change in VEZT protein expression in subset of endometrial tissue samples $(\mathrm{n}=122)$ concluding further validation was needed of a relationship between SNP and gene expression levels.

Using in-vitro approaches and blood eQTL analysis a SNP at rs12038474 was found to be located in transcriptional silencer for $C D C 42$ and to increase its expression in reporter assays (Powell et al., 2016). CDC42 is a member of the Rho family of GTPase signalling molecules and its overexpression in some cancers has been implicated in increased cell migration. Other studies have reported that stromal and stem cells from women with endometriosis have an altered phenotype associated with enhanced migration and suggested this may involve Rho/ROCK signalling pathways (Yotova et al., 2011). Therapies targeting CDC42 dependent pathways are being explored as treatments for cancers with high mortality such as NSCLC (non-small cell lung cancer (Tan et al., 2020). Expression of CDC42 was previously investigated using immunostaining of eutopic and ectopic endometrium in 19 patients with ovarian endometriosis (Goteri et al., 2006) with some weak evidence of increased expression in secretory phase endometrium in those with disease.

\section{Evidence from genomic studies supporting a role for sex steroids in the aetiology of endometriosis}

Evidence from GWAS (Table 2) appear consistent with a role for genetic mutations in genes implicated in steroid regulation of the endometrium in modifying the risk of developing endometriosis. Follow up studies, reviewed briefly below, have been conducted which have 
further strengthened this evidence and complemented studies on individual hormone dependent gene expression in endometrial cells and tissues (Burney et al., 2007).

In a meta-analysis Nyholt and collaborators used data from 11 GWAS case-control data sets with more than 17,000 endometriosis cases (Table 2 (Sapkota et al., 2017)). They replicated previous reported loci and identified five novel SNPs significantly associated with genes involved in sex steroid hormone signalling pathways including FSH beta $(F S H B)$, fibronectin (FN1) and CCDC170 a gene implicated in breast cancer risk (Dunning et al., 2016) and five secondary association signals, including two at the ESR1 locus.

SNPs associated with the ESR1 gene and GREB1, an early response gene in the oestrogen receptor (ER)-regulated pathway, have been a consistent findings in multiple endometriosis GWAS including large scale meta-analysis (Rahmioglu et al., 2014; Sapkota et al., 2017) although other studies have failed to replicate findings of an association with the rs 11674184 SNP of the GREB1 gene (Matalliotaki et al., 2019). Oestrogen receptors play a key role in regulation of endometrial function and it is notable that many studies have recorded disregulation of ESR1/ESR2 with overexpression of the latter in endometriosis lesions (Table 1) which has been attributed to changes in methylation status of ESR2 (Xue et al., 2007a) rather than genomic SNPs.

In a recent paper Marla et al (Marla et al., 2021) examined hormonal and genetic regulation of genes in the ESRl region in endometrium and explored the effect of endometriosis risk variants. The authors noted that variants in the ESRI region of SNPs associated with endometriosis risk were not the same as the ESR1 SNPs associated with age at first birth, age at menarche or breast cancer which is something that needs to be born in mind when linking risks to pathways.

SNPs associated with HOXA10 (7p15.2) have reported in more than one GWAS (Nyholt et al., 2012; Painter et al., 2011a). HOXA10 is upregulated in endometrial stromal cells as they decidualize and it plays a key role in regulating other genes implicated in regulation of metabolism, DNA replication and repair, cell junction, and lysosome and signal transduction (Wang et al., 2021). Miss-expression of HOXA10 has been reported to contribute to infertility (Ashary et al., 2020) and mice with deletion of Hoxa10 have severe defects in decidualization and implantation (Gao et al., 2015). More recent studies have suggested altered expression of HOXA10 (Fischer et al., 2011) might also be a risk factor for adenomyosis (abnormal invasion of endometrium into the myometrium) which is a often found as co-morbitity of endometriosis supporting suggestions that these conditions share common risk factors [online ahead of print doi: 10.1093/humupd/dmab017].

Members of the Wnt gene family are well established as regulators of endometrial cell function with important roles in epithelial-mesenchyme interactions (Tulac et al., 2003). SNPs associated with WNT4 (at 1p36.12) have been a consistent finding in several GWAS (Rahmioglu et al., 2014). This gene encodes a secreted signaling factor that regulates both development of endometrial glands and progesterone signaling during decidualization (Franco et al., 2011; Hayashi et al., 2011). In a study comparing expression of WNT4 in eutopic and ectopic endometrium of 30 patients with endometrium from 30 controls some evidence was presented for downregulation in ectopic endometrium and in eutopic endometrium of patients compared with controls (Liang et al., 2016) adding weight to a role for WNT4 in the disease although more extensive studies to link SNPs to gene expression are required.

\section{Genomic studies have revealed links between endometriosis reproductive traits and other disorders}


The increase in GWAS studies has opened up the opportunity to compare SNPs in women with endometriosis and those identified as associated with reproductive traits and reproductive or other disorders (Table 3). A number of these comparisons have strengthened the evidence for involvement of pathways involving genes that are hormone regulated.

Younger age at menarche has been implicated in increased risk of developing endometriosis as have short menstrual cycles and low body mass index whereas having more children is associated with lower risk (Shafrir et al., 2018). A number of GWAS studies have shed light on the heritable factors that may contribute to these characteristics and in some cases comparisons have also been made to endometriosis datasets. For example, a large scale GWAS has identified a genetic component to age at first birth and number of children with 12 loci including a SNP associated with ESRl (rs4851269) (Barban et al., 2016). There is also evidence from GWAS studies for a shared genetic risk factors between ovarian ageing and premature ovarian failure (McGrath et al., 2021). A preprint article [https://doi.org/10.1101/401448] which has not yet been peer reviewed reported a GWAS of endometriosis-related infertility, including 2,969 cases and 3,770 controls; they did not confirm genome-wide significance for any SNPs associated with endometriosis-related infertility although they recorded 3 SNPs at or near genes implicated in female fertility in model organisms.

To identify loci for age at menarche, a meta-analysis of 32 genome-wide association studies in 87,802 women of European descent, with replication in up to 14,731 women was performed resulting in the identification of more than 30 new SNP loci (Elks et al., 2010). Notably three of these were in or near genes implicated in hormonal regulation (INHBA, PCSK2 and RXRG). A more recent small-scale study took 52 of the candidate SNPs for age at menarche and their gene-gene and gene-environment interactions and analysed whether they were associated with endometriosis using samples from 395 patients and 981 controls (Ponomarenko et al., 2020a). They found 16 SNPs that were associated with endometriosis and evidence for a link with the $\mathrm{G}$ protein signalling pathway. One of the most well-established associations with age at menarche is body size with early studies indicating this is regulated by genetic factors rather than diet (Stark et al., 1989). It is therefore of note that Rahmioglu and colleagues have reported a significant enrichment of common SNPs when comparing datasets based on fat distribution and endometriosis (Rahmioglu et al., 2015) including shared genes associated with the WNT signalling pathway (Table 3). A recent analysis using two-sample randomization analysis also found evidence that reduced body weight/BMI and variants that expose women to more episodes of menstruation might be mediating genetic susceptibility to endometriosis (Garitazelaia et al., 2021) which backs up epidemiological and other genetic data including GWAS discussed above.

Comparisons have made between GWAS from endometriosis patients and those from women with fibroids (leiomyomata) (Gallagher et al., 2019). A meta-analysis reported that genes associated with endometriosis that were involved in hormone-signalling (WNT4/CDC42, GREB1, ESR1, FSHB) were also associated with diagnosis of fibroids. The authors reported that there was at least a doubling of risk for a diagnosis of fibroids among those with a history of endometriosis suggesting overlapping genetic origins. Notably candidate genes identified for age at menarche are also associated with presence of fibroids. A recent study reported that of the 23 loci associated with fibroids 16 were associated with either age at menarche (7 SNPs) or height and/or body mass index (BMI) (13 SNPs) (Ponomarenko et al., 2020b). One of the SNPs associated with at least two of the three phenotypes being rs4374421 (LHCGR) consistent with an important role for hormones/receptors in regulation of multiple reproductive phenotypes. 
Epidemiological and array studies have identified an increased risk of developing some forms of ovarian cancer in women with endometriosis ( $\mathrm{Lu}$ et al., 2015). Comparisons between endometriosis and endometrial cancer datasets (Painter et al., 2018) highlighted 13 distinct loci associated in both endometriosis and endometrial cancer. The study suggested that endometriosis and endometrial cancer have a moderate, but significant, shared genetic aetiology. Recently Japanese researchers performed GWAS studies of two benign gynecologic diseases (endometriosis, fibroids) and three reproductive cancers (ovarian, endometrial, cervical) using data of 46,837 subjects and 39,556 matched female controls from the Japan Biobank Project (Masuda et al., 2020). They reported genetic correlations were relatively strong between ovarian cancer and endometriosis and also confirmed a weaker association between endometriosis and fibroids as well as SNPs in endometrial and ovarian cancer unique to Japanese and/or East Asians.

The finding of common SNPs between endometriosis and migraine (Adewuyi et al., 2020) is interesting because they align with reports that migraine is more common in women than men; many women report worse symptoms during menstruation suggestive of an impact of hormones. The comorbidity of endometriosis with migraine has been reported in a number of epidemiological studies (Yang et al., 2012). In a twin based study of 815 monozygotic and 457 dizygotic female twin pairs Nyholt and colleagues reported a significant additive genetic correlation and bivariate heritability between migraine and endometriosis (Nyholt et al., 2009). GWAS meta-analysis of endometriosis and migraine datasets did not find novel genome-wide significant SNPs nor evidence of a causal link however they did identify some with shared genetically-controlled biological mechanisms which might explain the co-occurrence of the two disorders. These included several signalling pathways previously noted in similar SNP studies on endometriosis such as IL1R, MAP kinase and Akt-mTOR (Adewuyi et al., 2020).

Depression and fatigue are symptoms commonly reported by women with endometriosis (Saunders and Horne, 2021). A meta-analysis of endometriosis and depression GWAS (sample size 709,111), identified 20 independent genome-wide significant loci of which eight were novel (Adewuyi et al., 2021). Genes overlapping the two traits were significantly enriched for the biological pathways 'cell-cell adhesion', 'inositol phosphate metabolism', 'Hippo-Merlin signaling dysregulation' and 'gastric mucosa abnormality'.

\section{Have genomic studies provided any new diagnostic or therapeutic insights?}

Genetic changes identified by GWAS or other methods based on sequencing of DNA arise in the germ line and their impact may therefore be at any time during formation, differentiation or function of a differentiated tissue. The results from these approaches can be complemented by analysis of cells recovered from lesions or in the endometrium of women with endometriosis which can yield information on somatic mutations, epigenetic changes and transcriptomes. Notably in the case of SNP data it has been hoped that we might develop a panel of genetic changes that could explain inherited traits with the potential of being used as a screening test reducing the need for surgical diagnosis. To date this has not proved viable and results with screening for non-coding miRNAs have shown more promise (Moustafa et al., 2020).

The endometrium is highly sensitive to the actions of sex steroids and therefore an apparent association between genetic variants that have an impact on steroid receptor expression and/or steroid signalling would appear to fit with what is known about the disorder. It is also notable that shared SNPs have been identified between endometriosis and other hormone-dependent reproductive disorders including fibroids and endometrial cancer. This is complemented by extensive evidence that sex steroids alter the function of endometrial tissue, endometrial 
immune cells and cross-talk between inflammatory and other cells within the lesions (reviewed in (Saunders and Horne, 2021).

Some of the most promising and potentially useful information arising from the genetic studies has been the identification of SNPs associated with other traits and disorders. In the case of migraine there is already discussion surrounding repurposing of drugs used to treat migraine for treatment of endometriosis-associated pain (Saunders and Horne, 2021). Likewise reports that GWAS analysis of datasets related to depression and comparison to those of endometriosis identified a link to 'gastric mucosa abnormality' (Adewuyi et al., 2021) may provide a link to evidence that the gut-brain axis can play a role in pain pathways (Muller et al., 2020) and invigorate studies on dietary modification as a non-drug therapy for both conditions.

\section{Conclusions and Future perspectives}

A study on Korean women which explored familial cases of endometriosis found shared risk factors/SNPs suggested women with an affected sibling, early menarche, low BMI or who smoked could be considered an at-risk population (Kim et al., 2021). This highlights the power of combining information from several studies to move the field forward towards the goal of personalised risk assessment. Notably this study was conducted in Asia whereas nearly all the other GWAS have focused on populations with European ancestry: there is clearly an urgency to increase the ethnic diversity of populations studied in GWAS for all reproductive traits and disorders. Another notable limitation of many of the findings from existing GWAS is that the most significant findings with the most robust statistical significance have only been associated with more extensive disease (stages III/IV). This may suggest genetic changes play a more important role in the aetiology of this subset of women but we cannot conclude this is the case without additional data from well phenotyped individuals with a stage I/II diagnosis.

A recent paper using whole genome sequencing of members of an affected family with ovarian endometriosis shows the power of this approach to identify novel mutations (Albertsen et al., 2019). The rapidly reducing cost of whole genome sequencing is likely to increase the use of this approach for familial cases and could be one way to increase early diagnosis.

Montgomery and colleagues have argued that we may achieve additional breakthroughs in our understanding of the role(s) of gene mutations in the origins and pathogenesis of the disorder (Montgomery et al., 2020) by expanding our studies on somatic mutations in epithelial cells within the eutopic endometrium many of which may arise early in life (Lac et al., 2019) and this is clearly an important area for future work. Gene expression in the endometrium will also be influenced by epigenetic changes to the genome and a number of investigators have explored this mechanism in the context of steroid regulation of endometriosis by comparing patterns between eutopic and ectopic endometrium (reviewed in (Borghese et al., 2017). These studies have expanded on those targeting specific genes such as ESR2 (Xue et al., 2007a). A recent study used stromal cells isolated from eutopic endometrium during the proliferative phase from patients as well as in vitro cultures with $\mathrm{E} 2$ and/or progesterone in combination with analysis of the DNA methylome to compare epigenetic landscape and see if this was altered in patients (Houshdaran et al., 2020). The authors reported finding pre-existing aberrant DNA methylation signatures in the cells from women with endometriosis and that these were not uniform throughout the patient group with those found in women with stage IV disease associated with a blunting of response to E2 treatment. The other regulatory pathway that has been investigated in the context of hormone regulation of endometrium/endometriosis is that of non-coding RNAs (Nothnick et al., 2019; Vashisht et al., 2020). Whilst outside the scope of this review the miRNA field is a rapidly expanding one with some promising results linking miRNAs to disease mechanisms (Stejskalova et al., 2021). Further studies on epigenetic changes in the 
genome and non-coding RNA pathways are anticipated but they also need to be more closely integrated with the insights from genomic studies.

In summary, the rapid explosion in the use of unbiased genomic approaches such as GWAS has led to a large body of data that consistently reports mutations in areas of the genome that appear associated with genes that regulate hormone-dependent gene expression (receptors, enzymes, transcription factors). These changes are candidates for increasing the risk of developing the disorder as well as some common co-morbidities reported by patients. The next challenge is to integrate these data with changes in cell/tissue function and to use them as a platform for improvements in diagnosis and care. 


\section{Tables}

Table 1. Summary of selected key studies that have provided evidence for altered steroid biosynthesis and/or action in eutopic endometrium or endometriosis lesions from patients

\begin{tabular}{|c|c|c|c|}
\hline Title/topic & Methods & Results & References \\
\hline $\begin{array}{l}\text { Expression of ESR1 vs } \\
\text { ESR2 in endometriosis } \\
\text { lesions compared with } \\
\text { endometrium }\end{array}$ & $\begin{array}{l}\text { Fibroblasts isolated } \\
\text { from endometrioma } \\
\text { and endometrium, } \\
\text { immunohistochemistry, } \\
\text { evaluation of } \\
\text { methylation status of } \\
\text { ESR2 promoter }\end{array}$ & $\begin{array}{l}\text { ESR2 overexpressed in } \\
\text { lesions compared with } \\
\text { ESR1; mechanism } \\
\text { involving altered } \\
\text { methylation }\end{array}$ & $\begin{array}{l}\text { (Xue et al., } \\
\text { 2007a; Xue et } \\
\text { al., 2007b) }\end{array}$ \\
\hline $\begin{array}{l}\text { Gene expression } \\
\text { analysis of } \\
\text { endometrium reveals } \\
\text { progesterone resistance } \\
\text { and candidate } \\
\text { susceptibility genes in } \\
\text { women with } \\
\text { endometriosis }\end{array}$ & $\begin{array}{l}\text { Endometrial tissue } \\
\text { biopsies from } 21 \\
\text { women with } \\
\text { endometriosis and } 16 \\
\text { women without, cycle } \\
\text { stage determined. } \\
\text { Affymetrix } \\
\text { arrays+gene ontogeny }\end{array}$ & $\begin{array}{l}\text { Phase-dependent } \\
\text { changes in gene } \\
\text { expression both tissue } \\
\text { sets. Patient samples - } \\
\text { enrichment of genes } \\
\text { involved in proliferation } \\
\text { in early secretory phase } \\
\text { disregulation of P target } \\
\text { genes in secretory phase }\end{array}$ & $\begin{array}{l}\text { (Burney et al., } \\
2007 \text { ) }\end{array}$ \\
\hline $\begin{array}{l}\text { Gene expression profile } \\
\text { for ectopic versus } \\
\text { eutopic endometrium } \\
\text { provides new insights } \\
\text { into endometriosis } \\
\text { oncogenic potential }\end{array}$ & $\begin{array}{l}\text { Paired samples of } \\
\text { endometriomas and } \\
\text { endometrium ( } 12 \\
\text { women, luteal phase). } \\
\text { Nimgen microarrays, } \\
\text { validation } 20 \text { genes, } \\
\text { pathway analysis } \\
\text { (DAVID) }\end{array}$ & $\begin{array}{l}\text { Cluster dependent } \\
\text { modulation of HOX } \\
\text { genes } \\
\text { Altered cell cycle genes } \\
\text { (suppressed?) }\end{array}$ & $\begin{array}{l}\text { (Borghese et } \\
\text { al., 2008b) }\end{array}$ \\
\hline $\begin{array}{l}\text { Prostaglandin E2 via } \\
\text { SF-1 coordinately } \\
\text { regulates transcription } \\
\text { of steroidogenic genes } \\
\text { necessary for estrogen } \\
\text { synthesis in } \\
\text { endometriosis }\end{array}$ & $\begin{array}{l}\text { Stromal cells isolated } \\
\text { from wall of } \\
\text { endometriomas (17) } \\
\text { and endometrium (16), } \\
\text { extra-ovarian tissue } \\
\text { different group of } \\
\text { women (13). RTPCR } \\
\text { steroid enzyme } \\
\text { mRNAs, ChIP assays }\end{array}$ & $\begin{array}{l}\text { StAR, P450scc, } \\
\text { P450c17, P450arom } \\
\text { higher in ectopic } \\
\text { samples. SF1 high and } \\
\text { binds promoter of StAR }\end{array}$ & $\begin{array}{l}\text { (Attar et al., } \\
\text { 2009; Yilmaz } \\
\text { and Bulun, } \\
\text { 2019) }\end{array}$ \\
\hline $\begin{array}{l}\text { Intra-tissue steroid } \\
\text { profiling and enzyme } \\
\text { analysis confirms } \\
\text { differences in steroid } \\
\text { metabolism in the } \\
\text { endometrium and } \\
\text { endometriosis lesions }\end{array}$ & $\begin{array}{l}\text { RTPCR analysis of } \\
\text { enzymes in lesions vs } \\
\text { endometrium, LC- } \\
\text { MS/MS for direct } \\
\text { measurement of steroid } \\
\text { concentrations }\end{array}$ & $\begin{array}{l}\text { Altered tissue steroid } \\
\text { concentrations in } \\
\text { endometriosis altered } \\
\text { expression of various } \\
\text { steroidogenic enzymes } \\
\text { HSD3B2 high } \\
\text { CYP11A1 low }\end{array}$ & $\begin{array}{l}\text { (Huhtinen et } \\
\text { al., 2014), } \\
\text { (Huhtinen et } \\
\text { al., 2012; } \\
\text { Rizner, 2009) }\end{array}$ \\
\hline $\begin{array}{l}\text { Steroid receptor } \\
\text { expression in } \\
\text { endometrial progenitor } \\
\text { populations }\end{array}$ & $\begin{array}{l}\text { Isolation of side } \\
\text { population cells (lines } \\
\text { and xenografting } \\
\text { successful). SUSD2+ } \\
\text { progenitors from } \\
\text { endometrium } \\
\text { (clonogenic potential) }\end{array}$ & $\begin{array}{l}\text { SP cells did not express } \\
\text { either ERalpha or } \\
\text { progesterone receptor } \\
\text { (PR). SUSD2+ cells did } \\
\text { not express ERalpha }\end{array}$ & $\begin{array}{l}\text { (Cervello et } \\
\text { al., 2011), } \\
\text { (Ulrich et al., } \\
\text { 2014) }\end{array}$ \\
\hline
\end{tabular}


Table 2. Larger GWAS studies that have identified common SNP variants associated with endometriosis

\begin{tabular}{|c|c|c|c|c|}
\hline Patients & Controls & SNPs & Genes/pathways & reference \\
\hline $\begin{array}{l}3194 \text { surgically } \\
\text { confirmed } \\
\text { (UK/Australia) }\end{array}$ & $\begin{array}{l}\text { population } \\
\text { controls } 7060 \\
\text { (UK/Australia) }\end{array}$ & $\begin{array}{l}\text { 7p15.2 strongest } \\
\text { in subgroup with } \\
\text { stage III/IV } \\
\text { disease } \\
\text { rs12700667 }\end{array}$ & $\begin{array}{l}\text { intergenic region } \\
\text { upstream of } \\
\text { NFE } 2 L 3 \text {, } \\
\text { HOXA10/A11 }\end{array}$ & $\begin{array}{l}\text { (Painter et al., } \\
\text { 2011a) }\end{array}$ \\
\hline $\begin{array}{l}3223 \text { women } \\
\text { with surgically } \\
\text { confirmed } \\
\text { endometriosis, } \\
1090 \text { women } \\
\text { without } \\
\text { endometriosis }\end{array}$ & $\begin{array}{l}\text { population } \\
\text { controls } 7060\end{array}$ & $\begin{array}{l}\text { examined } 11984 \\
\text { SNPs on } \\
\text { chromosome } 10 . \\
\text { Signal 10q26 } \\
\text { rs11592737 } \\
\text { replicated }\end{array}$ & CYP2C19 & $\begin{array}{l}\text { (Painter et al., } \\
\text { 2011b) }\end{array}$ \\
\hline 4604 & $\begin{array}{l}9393 \text { women of } \\
\text { Japanese and } \\
\text { European } \\
\text { ancestry }\end{array}$ & $\begin{array}{l}\text { rs12700667 } \\
\text { replicated in } \\
\text { Japanese } \\
\text { rs7521902 at } \\
1 \text { p36.12 } \\
\text { rs13394619 at } \\
2 \text { p25 }\end{array}$ & $\begin{array}{l}\text { NFE2L3, } \\
\text { HOXA10 } \\
\text { WNT4 } \\
\text { GREB1 }\end{array}$ & $\begin{array}{l}\text { (Nyholt et al., } \\
2012 \text { ) }\end{array}$ \\
\hline $\begin{array}{l}\text { meta-analysis } \\
11506 \text { cases } \\
\text { stage III/IV } 2859\end{array}$ & $\begin{array}{l}32678 \text { (European } \\
\text { and Japanese) }\end{array}$ & $\begin{array}{l}8 \text { of } 9 \text { loci } \\
\text { stronger effect in } \\
\text { stage II/IV } \\
\text { rs1537377 } \\
\text { rs13394619 } \\
\text { rs12700667 } \\
\text { rs7521902 } \\
\text { rs7739264 }\end{array}$ & $\begin{array}{l}\text { CDKN2B-AS1 } \\
\text { GREB1 } \\
\text { WNT4 } \\
\text { VEZT } \\
\text { ID4 }\end{array}$ & $\begin{array}{l}\text { (Rahmioglu et } \\
\text { al., 2014) }\end{array}$ \\
\hline $\begin{array}{l}3908 \text { diagnosis of } \\
\text { endometriosis }\end{array}$ & $\begin{array}{l}8568 \text { women of } \\
\text { Japanese and } \\
\text { European } \\
\text { ancestry }\end{array}$ & $\begin{array}{l}\text { rs6542095, } \\
\text { rs3783550 } \\
\text { rs3783525 }\end{array}$ & IL4 locus & $\begin{array}{l}\text { (Sapkota et al., } \\
\text { 2015b) }\end{array}$ \\
\hline 2594 & 4496 controls & $\begin{array}{l}\text { rs3820282 } \\
\text { rs12038474 } \\
+ \text { blood eQTL }\end{array}$ & $\begin{array}{l}\text { interactions with } \\
\text { promoters of } \\
\text { LINC00339, } \\
C D C 42 \text { (silencer) }\end{array}$ & $\begin{array}{l}\text { (Powell et al., } \\
2016)\end{array}$ \\
\hline $\begin{array}{l}3194 \text { (surgical } \\
\text { confirmed) Stage } \\
\text { I/II 1686; stage } \\
\text { III/IV 1364 }\end{array}$ & $\begin{array}{l}7060 \text { controls } \\
\text { European } \\
\text { ancestry }\end{array}$ & $\begin{array}{l}\text { rs144240142 } \\
\text { (intronic } \\
\text { MAP3K4) }\end{array}$ & $\begin{array}{l}\text { MAPK signalling } \\
\text { pathway } \\
\text { ECM } \\
\text { glycoprotein }\end{array}$ & $\begin{array}{l}\text { (Uimari et al., } \\
\text { 2017) }\end{array}$ \\
\hline $\begin{array}{l}\text { metanalysis } \\
17,045 \text { cases }\end{array}$ & 191,596 controls & $\begin{array}{l}\text { FN1, CCDC170, } \\
\text { ESR1, SYNE1 } \\
\text { and FSHB }\end{array}$ & $\begin{array}{l}\text { steroid receptors } \\
\text { and steroid } \\
\text { signalling }\end{array}$ & $\begin{array}{l}\text { (Sapkota et al., } \\
\text { 2017) }\end{array}$ \\
\hline $\begin{array}{l}\text { Pooled GWAS, } \\
\text { endometrioma, } \\
\text { Han Chinese } \\
\text { women } 50 \\
\text { primary and } 1448 \\
\text { for validation }\end{array}$ & $\begin{array}{l}1540 \text { (had } \\
\text { secondary } \\
\text { infertility or } \\
\text { fibroids) }\end{array}$ & 10 novel loci & $\begin{array}{l}\text { most significant } \\
\text { IGF1R } \\
\text { (signalling) } \\
\text { Meis homeobox }\end{array}$ & $\begin{array}{l}\text { (Wang et al., } \\
\text { 2017) }\end{array}$ \\
\hline
\end{tabular}


Table 3. GWAS Studies that have identified SNPs in common with endometriosis

\begin{tabular}{|c|c|c|c|c|}
\hline Condition & $\begin{array}{l}\text { Cohort for non- } \\
\text { endo condition }\end{array}$ & $\begin{array}{l}\text { SNP overlap } \\
\text { with } \\
\text { endometriosis }\end{array}$ & $\begin{array}{l}\text { Target } \\
\text { genes/pathways }\end{array}$ & References \\
\hline Fibroids & $\begin{array}{l}35,474 \text { cases and } \\
267,505 \text { female } \\
\text { controls of } \\
\text { European ancestry }\end{array}$ & $\begin{array}{l}\text { 1p36.12, } \\
\text { rs } 7412010 ; \\
2 \text { p25.1, } \\
\text { rs35417544; } \\
6 q 25.2 \\
\text { rs58415480; } \\
11 p 14.1 \\
\text { rs11031006 }\end{array}$ & $\begin{array}{l}\text { WNT4, CDC42, } \\
\text { GREB1, ESR1, } \\
\text { FSHB }\end{array}$ & $\begin{array}{l}\text { (Gallagher et } \\
\text { al., 2019) }\end{array}$ \\
\hline Age at menarche & $\begin{array}{l}395 \text { patients (endo) } \\
981 \text { controls }\end{array}$ & $\begin{array}{l}52 \text { SNPs } \\
\text { previously } \\
\text { identified for } \\
\text { age at } \\
\text { menarche: } 16 \\
\text { SNP overlap } \\
\text { with endo } \\
\text { rs6589964 }\end{array}$ & $\begin{array}{l}28 \text { genes in } \mathrm{G} \\
\text { alpha signalling } \\
\text { pathway; } L H C G R \\
\text { several SNPs } \\
\text { (strong) } \\
B S X \text { - increases } \\
\text { affinity for FOXA } \\
\text { transcription } \\
\text { factors }\end{array}$ & $\begin{array}{l}\text { (Ponomarenko } \\
\text { et al., 2020a) }\end{array}$ \\
\hline Endometrial Cancer & $\begin{array}{l}4 \text { datasets } \\
6459 \text { patients } \\
32,624 \text { controls }\end{array}$ & $\begin{array}{l}13 \text { loci incl } \\
\text { rs } 2475335 \\
\text { located in } \\
\text { PTPRD }\end{array}$ & STAT3 pathway & $\begin{array}{l}\text { (Painter et al., } \\
\text { 2018) }\end{array}$ \\
\hline Ovarian Cancer & $\begin{array}{l}10065 \text { cases and } \\
21663 \text { controls }\end{array}$ & $\begin{array}{l}\text { Clear cell } \\
\text { carcinoma } \\
\text { showed the } \\
\text { strongest } \\
\text { genetic } \\
\text { correlation } \\
\text { with } \\
\text { endometriosis }\end{array}$ & $? ?$ & $\begin{array}{l}\text { (Lu et al., } \\
2015)\end{array}$ \\
\hline Obesity/Leanness & $\begin{array}{l}\text { BMI (GIANT; } \\
123,865 \\
\text { individuals) and } \\
\text { WHRadjBMI } \\
\text { (GIANT: } 77,167 \\
\text { individuals) }\end{array}$ & $\begin{array}{l}7 \mathrm{p} 15.2 \\
\text { KIFAP3 and } \\
\text { CAB39L, are } \\
\text { novel } \\
\text { associations for } \\
\text { both traits }\end{array}$ & $\begin{array}{l}\text { Wnt pathway (3 } \\
\text { genes) }\end{array}$ & $\begin{array}{l}\text { (Rahmioglu et } \\
\text { al., 2015) }\end{array}$ \\
\hline Migraine & $\begin{array}{l}22 \text { GWAS, } 59,674 \\
\text { migraine cases and } \\
316,078 \text { controls } \\
\text { (sex considered as } \\
\text { a covariant) }\end{array}$ & $\begin{array}{l}\text { SNPs near } \\
\text { SLC35G6 } \\
\text { TRIM32 } \\
\text { ARL14EP }\end{array}$ & $\begin{array}{l}\text { IL1R binding, } \\
\text { PI3K-Akt-mTOR- } \\
\text { signaling, } \\
\text { MAPK signalling } \\
\text { TNF- } \alpha \text { signalling }\end{array}$ & $\begin{array}{l}\text { (Adewuyi et } \\
\text { al., 2020) }\end{array}$ \\
\hline Depression & $\begin{array}{l}170,756 \text { cases of } \\
\text { depression } 329,443 \\
\text { controls } \\
\text { European ancestry }\end{array}$ & $\begin{array}{l}20 \text { independent } \\
\text { loci, } 8 \text { novel }\end{array}$ & $\begin{array}{l}\text { Causal } \\
\text { relationship? } \\
\text { Gastric mucosal } \\
\text { abnormality }\end{array}$ & $\begin{array}{l}\text { (Adewuyi et } \\
\text { al., 2021) }\end{array}$ \\
\hline
\end{tabular}


Figure 1.

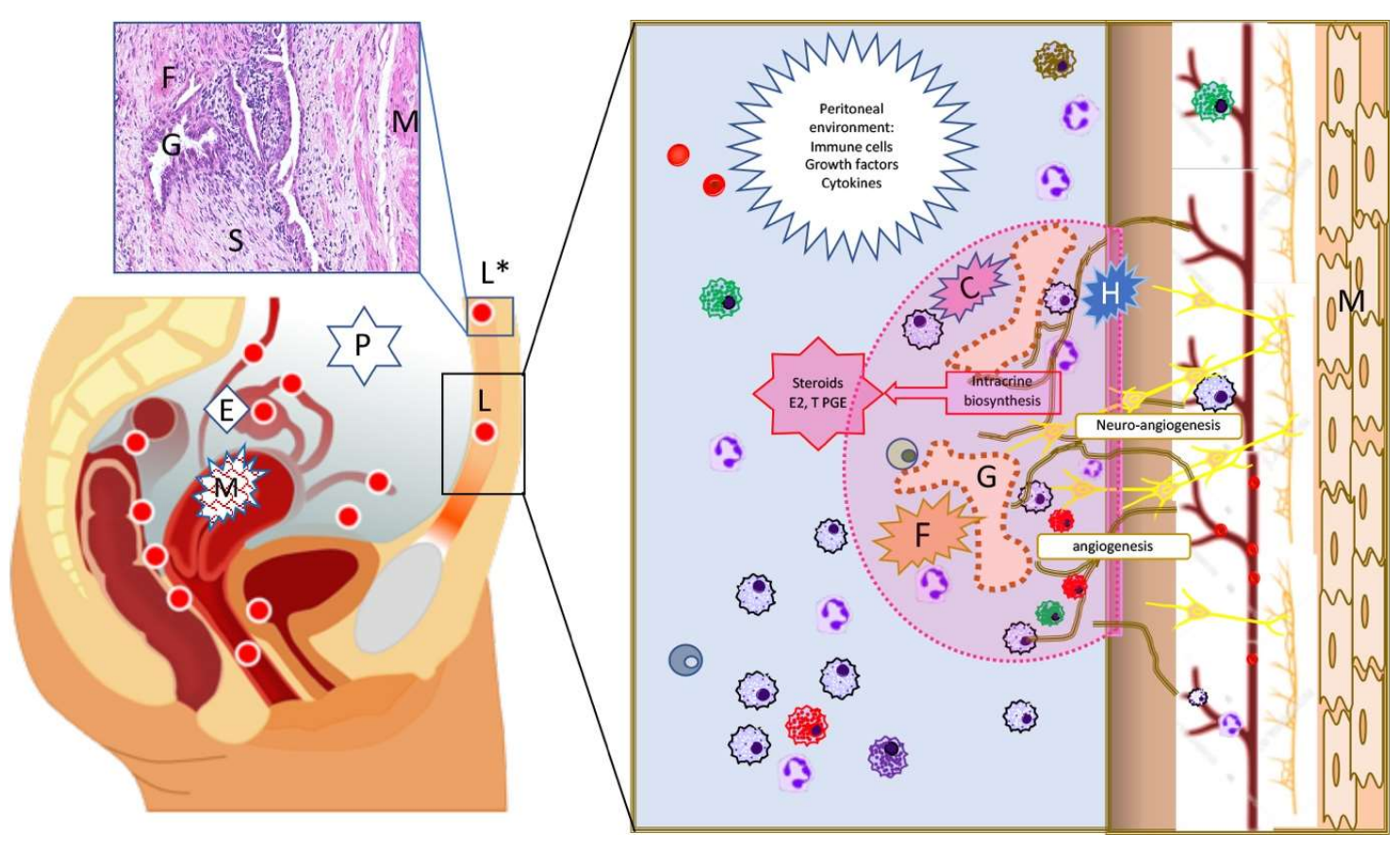

Figure 1. Location and histology of endometriosis lesions.

Endometriosis lesions are predominantly found in the pelvic cavity where they may be associated with the peritoneal wall (superficial peritoneal), the ovary (cysts/endometriomas) or as nodules (deep endometriosis) associated with areas of fibrosis and adhesions between bowel, bladder and vagina (lower left diagram shown as red circles). A histological section of a superficial peritoneal lesion (*) stained with H\&E is shown above the diagram of the pelvic cavity. The lesion is supported by the peritoneal wall which has a layer of smooth muscle (M) and it contains stromal fibroblasts (S), myofibroblasts (fibrosis, F) and a gland surrounded by epithelial cells $(\mathrm{G})$. The right-hand panel shows a diagramatic representation of a lesion (surrounded by dotted pink line) mirroring the histology of the H\&E image complemented by representation of additional cell types including nerves (yellow), blood vessels (brown) and immune cells (variety of colours). Processes which contribute to lesion survival (angiogenesis), growth of nerves in lesions (neuroangiogenesis) and creation of a unique environment that has high concentrations of steroids (intracrine biosynthesis, (Huhtinen et al., 2014; Rizner, 2009)). 


\section{References}

(1997). Revised American Society for Reproductive Medicine classification of endometriosis: 1996. Fertil Steril 67, 817-821.

Adewuyi, E.O., Mehta, D., Sapkota, Y., International Endogene, C., andMe Research, T., Auta, A., Yoshihara, K., Nyegaard, M., Griffiths, L.R., Montgomery, G.W., et al. (2021). Genetic analysis of endometriosis and depression identifies shared loci and implicates causal links with gastric mucosa abnormality. Hum Genet 140, 529-552.

Adewuyi, E.O., Sapkota, Y., International Endogene Consortium, I., andMe Research, T., International Headache Genetics Consortium, I., Auta, A., Yoshihara, K., Nyegaard, M., Griffiths, L.R., Montgomery, G.W., et al. (2020). Shared Molecular Genetic Mechanisms Underlie Endometriosis and Migraine Comorbidity. Genes (Basel) 11.

Aghajanova, L., Hamilton, A., Kwintkiewicz, J., Vo, K.C., and Giudice, L.C. (2009).

Steroidogenic enzyme and key decidualization marker dysregulation in endometrial stromal cells from women with versus without endometriosis. Biol Reprod 80, 105-114.

Albertsen, H.M., Matalliotaki, C., Matalliotakis, M., Zervou, M.I., Matalliotakis, I., Spandidos, D.A., Chettier, R., Ward, K., and Goulielmos, G.N. (2019). Whole exome sequencing identifies hemizygous deletions in the UGT2B28 and USP17L2 genes in a threegeneration family with endometriosis. Mol Med Rep 19, 1716-1720.

Andres, M.P., Arcoverde, F.V.L., Souza, C.C.C., Fernandes, L.F.C., Abrao, M.S., and Kho, R.M. (2020). Extrapelvic Endometriosis: A Systematic Review. J Minim Invasive Gynecol 27, 373389.

Ashary, N., Laheri, S., and Modi, D. (2020). Homeobox genes in endometrium: from development to decidualization. Int J Dev Biol 64, 227-237.

Attar, E., Tokunaga, H., Imir, G., Yilmaz, M.B., Redwine, D., Putman, M., Gurates, B., Attar, R., Yaegashi, N., Hales, D.B., et al. (2009). Prostaglandin E2 via steroidogenic factor-1 coordinately regulates transcription of steroidogenic genes necessary for estrogen synthesis in endometriosis. J Clin Endocrinol Metab 94, 623-631.

Barban, N., Jansen, R., de Vlaming, R., Vaez, A., Mandemakers, J.J., Tropf, F.C., Shen, X., Wilson, J.F., Chasman, D.I., Nolte, I.M., et al. (2016). Genome-wide analysis identifies 12 loci influencing human reproductive behavior. Nat Genet 48, 1462-1472.

Bedaiwy, M.A., Falcone, T., Mascha, E.J., and Casper, R.F. (2006). Genetic polymorphism in the fibrinolytic system and endometriosis. Obstet Gynecol 108, 162-168.

Borghese, B., Chiche, J.D., Vernerey, D., Chenot, C., Mir, O., Bijaoui, G., Bonaiti-Pellie, C., and Chapron, C. (2008a). Genetic polymorphisms of matrix metalloproteinase 12 and 13 genes are implicated in endometriosis progression. Hum Reprod 23, 1207-1213.

Borghese, B., Mondon, F., Noel, J.C., Fayt, I., Mignot, T.M., Vaiman, D., and Chapron, C. (2008b). Gene expression profile for ectopic versus eutopic endometrium provides new insights into endometriosis oncogenic potential. Mol Endocrinol 22, 2557-2562.

Borghese, B., Zondervan, K.T., Abrao, M.S., Chapron, C., and Vaiman, D. (2017). Recent insights on the genetics and epigenetics of endometriosis. Clin Genet 91, 254-264.

Brighton, P.J., Maruyama, Y., Fishwick, K., Vrljicak, P., Tewary, S., Fujihara, R., Muter, J., Lucas, E.S., Yamada, T., Woods, L., et al. (2017). Clearance of senescent decidual cells by uterine natural killer cells in cycling human endometrium. Elife 6.

Burney, R.O., Talbi, S., Hamilton, A.E., Vo, K.C., Nyegaard, M., Nezhat, C.R., Lessey, B.A., and Giudice, L.C. (2007). Gene expression analysis of endometrium reveals progesterone 
resistance and candidate susceptibility genes in women with endometriosis. Endocrinology 148, 3814-3826.

Cervello, I., Mas, A., Gil-Sanchis, C., Peris, L., Faus, A., Saunders, P.T., Critchley, H.O., and Simon, C. (2011). Reconstruction of endometrium from human endometrial side population cell lines. PLoS One 6, e21221.

Critchley, H.O., Brenner, R.M., Henderson, T.A., Williams, K., Nayak, N.R., Slayden, O.D., Millar, M.R., and Saunders, P.T. (2001). Estrogen receptor beta, but not estrogen receptor alpha, is present in the vascular endothelium of the human and nonhuman primate endometrium. J Clin Endocrinol Metab 86, 1370-1378.

Critchley, H.O., Henderson, T.A., Kelly, R.W., Scobie, G.S., Evans, L.R., Groome, N.P., and Saunders, P.T. (2002). Wild-type estrogen receptor (ERbeta1) and the splice variant (ERbetacx/beta2) are both expressed within the human endometrium throughout the normal menstrual cycle. J Clin Endocrinol Metab 87, 5265-5273.

Critchley, H.O.D., Maybin, J.A., Armstrong, G.M., and Williams, A.R.W. (2020). Physiology of the Endometrium and Regulation of Menstruation. Physiol Rev 100, 1149-1179.

Dassen, H., Punyadeera, C., Kamps, R., Delvoux, B., Van Langendonckt, A., Donnez, J., Husen, B., Thole, H., Dunselman, G., and Groothuis, P. (2007). Estrogen metabolizing enzymes in endometrium and endometriosis. Hum Reprod 22, 3148-3158.

Dunn, C.L., Critchley, H.O., and Kelly, R.W. (2002). IL-15 regulation in human endometrial stromal cells. J Clin Endocrinol Metab 87, 1898-1901.

Dunning, A.M., Michailidou, K., Kuchenbaecker, K.B., Thompson, D., French, J.D., Beesley, J., Healey, C.S., Kar, S., Pooley, K.A., Lopez-Knowles, E., et al. (2016). Breast cancer risk variants at 6 q25 display different phenotype associations and regulate ESR1, RMND1 and CCDC170.

Nat Genet 48, 374-386.

Dunselman, G.A., Vermeulen, N., Becker, C., Calhaz-Jorge, C., D'Hooghe, T., De Bie, B., Heikinheimo, O., Horne, A.W., Kiesel, L., Nap, A., et al. (2014). ESHRE guideline:

management of women with endometriosis. Hum Reprod 29, 400-412.

Elks, C.E., Perry, J.R., Sulem, P., Chasman, D.I., Franceschini, N., He, C., Lunetta, K.L., Visser, J.A., Byrne, E.M., Cousminer, D.L., et al. (2010). Thirty new loci for age at menarche identified by a meta-analysis of genome-wide association studies. Nat Genet 42, 1077-1085. Fischer, C.P., Kayisili, U., and Taylor, H.S. (2011). HOXA10 expression is decreased in endometrium of women with adenomyosis. Fertil Steril 95, 1133-1136.

Forster, R., Sarginson, A., Velichkova, A., Hogg, C., Dorning, A., Horne, A.W., Saunders, P.T.K., and Greaves, E. (2019). Macrophage-derived insulin-like growth factor-1 is a key neurotrophic and nerve-sensitizing factor in pain associated with endometriosis. FASEB J 33, 11210-11222.

Franco, H.L., Dai, D., Lee, K.Y., Rubel, C.A., Roop, D., Boerboom, D., Jeong, J.W., Lydon, J.P., Bagchi, I.C., Bagchi, M.K., et al. WNT4 is a key regulator of normal postnatal uterine development and progesterone signaling during embryo implantation and decidualization in the mouse. FASEB J 25, 1176-1187.

Franco, H.L., Dai, D., Lee, K.Y., Rubel, C.A., Roop, D., Boerboom, D., Jeong, J.W., Lydon, J.P., Bagchi, I.C., Bagchi, M.K., et al. (2011). WNT4 is a key regulator of normal postnatal uterine development and progesterone signaling during embryo implantation and decidualization in the mouse. FASEB J 25, 1176-1187.

Gallagher, C.S., Makinen, N., Harris, H.R., Rahmioglu, N., Uimari, O., Cook, J.P., Shigesi, N., Ferreira, T., Velez-Edwards, D.R., Edwards, T.L., et al. (2019). Genome-wide association and 
epidemiological analyses reveal common genetic origins between uterine leiomyomata and endometriosis. Nat Commun 10, 4857.

Gao, F., Bian, F., Ma, X., Kalinichenko, V.V., and Das, S.K. (2015). Control of regional decidualization in implantation: Role of FoxM1 downstream of Hoxa10 and cyclin D3. Sci Rep 5, 13863.

Garitazelaia, A., Rueda-Martinez, A., Arauzo, R., de Miguel, J., Cilleros-Portet, A., Mari, S., Bilbao, J.R., Fernandez-Jimenez, N., and Garcia-Santisteban, I. (2021). A Systematic TwoSample Mendelian Randomization Analysis Identifies Shared Genetic Origin of Endometriosis and Associated Phenotypes. Life (Basel) 11.

Gellersen, B., and Brosens, J. (2003). Cyclic AMP and progesterone receptor cross-talk in human endometrium: a decidualizing affair. J Endocrinol 178, 357-372.

Gellersen, B., and Brosens, J.J. (2014). Cyclic decidualization of the human endometrium in reproductive health and failure. Endocr Rev 35, 851-905.

Gibson, D.A., Greaves, E., Critchley, H.O., and Saunders, P.T. (2015). Estrogen-dependent regulation of human uterine natural killer cells promotes vascular remodelling via secretion of CCL2. Hum Reprod 30, 1290-1301.

Gibson, D.A., McInnes, K.J., Critchley, H.O., and Saunders, P.T. (2013). Endometrial Intracrinology--generation of an estrogen-dominated microenvironment in the secretory phase of women. J Clin Endocrinol Metab 98, E1802-1806.

Gibson, D.A., Simitsidellis, I., Collins, F., and Saunders, P.T.K. (2020). Androgens, oestrogens and endometrium: a fine balance between perfection and pathology. J Endocrinol 246, R75R93.

Gibson, D.A., Simitsidellis, I., Cousins, F.L., Critchley, H.O., and Saunders, P.T. (2016). Intracrine Androgens Enhance Decidualization and Modulate Expression of Human Endometrial Receptivity Genes. Sci Rep 6, 19970.

Goteri, G., Ciavattini, A., Lucarini, G., Montik, N., Filosa, A., Stramazzotti, D., Biagini, G., and Tranquilli, A.L. (2006). Expression of motility-related molecule Cdc42 in endometrial tissue in women with adenomyosis and ovarian endometriomata. Fertil Steril 86, 559-565. Guo, S.W. (2018). Fibrogenesis resulting from cyclic bleeding: the Holy Grail of the natural history of ectopic endometrium. Hum Reprod 33, 353-356.

Hayashi, K., Yoshioka, S., Reardon, S.N., Rucker, E.B., 3rd, Spencer, T.E., DeMayo, F.J., Lydon, J.P., and MacLean, J.A., 2nd (2011). WNTs in the neonatal mouse uterus: potential regulation of endometrial gland development. Biol Reprod 84, 308-319.

Holdsworth-Carson, S.J., Fung, J.N., Luong, H.T., Sapkota, Y., Bowdler, L.M., Wallace, L., Teh, W.T., Powell, J.E., Girling, J.E., Healey, M., et al. (2016). Endometrial vezatin and its association with endometriosis risk. Hum Reprod 31, 999-1013.

Horne, A.W., and Saunders, P.T.K. (2019). SnapShot: Endometriosis. Cell 179, 1677-1677 e1671.

Houshdaran, S., Oke, A.B., Fung, J.C., Vo, K.C., Nezhat, C., and Giudice, L.C. (2020). Steroid hormones regulate genome-wide epigenetic programming and gene transcription in human endometrial cells with marked aberrancies in endometriosis. PLoS Genet 16, e1008601. Huhtinen, K., Saloniemi-Heinonen, T., Keski-Rahkonen, P., Desai, R., Laajala, D., Stahle, M., Hakkinen, M.R., Awosanya, M., Suvitie, P., Kujari, H., et al. (2014). Intra-tissue steroid profiling indicates differential progesterone and testosterone metabolism in the endometrium and endometriosis lesions. J Clin Endocrinol Metab 99, E2188-2197. Huhtinen, K., Stahle, M., Perheentupa, A., and Poutanen, M. (2012). Estrogen biosynthesis and signaling in endometriosis. Mol Cell Endocrinol 358, 146-154. 
Kim, H.J., Lee, H.S., Kazmi, S.Z., Hann, H.J., Kang, T., Cha, J., Choi, S., Swan, H., Kim, H., Lee, Y.S., et al. (2021). Familial Risk for Endometriosis and its Interaction with Smoking, Age At Menarche and Body Mass Index: A Population-Based Cohort Study Among Siblings. BJOG. Kitawaki, J., Obayashi, H., Ishihara, H., Koshiba, H., Kusuki, I., Kado, N., Tsukamoto, K., Hasegawa, G., Nakamura, N., and Honjo, H. (2001). Oestrogen receptor-alpha gene polymorphism is associated with endometriosis, adenomyosis and leiomyomata. Hum Reprod 16, 51-55.

Lac, V., Nazeran, T.M., Tessier-Cloutier, B., Aguirre-Hernandez, R., Albert, A., Lum, A., Khattra, J., Praetorius, T., Mason, M., Chiu, D., et al. (2019). Oncogenic mutations in histologically normal endometrium: the new normal? J Pathol 249, 173-181.

Lee, G.H., Kim, S.H., Choi, Y.M., Suh, C.S., Kim, J.G., and Moon, S.Y. (2007). Estrogen receptor beta gene $+1730 \mathrm{G} /$ A polymorphism in women with endometriosis. Fertil Steril 88, 785-788. Liang, Y., Li, Y., Liu, K., Chen, P., and Wang, D. (2016). Expression and Significance of WNT4 in Ectopic and Eutopic Endometrium of Human Endometriosis. Reprod Sci 23, 379-385.

Lu, Y., Cuellar-Partida, G., Painter, J.N., Nyholt, D.R., Australian Ovarian Cancer, S., International Endogene, C., Morris, A.P., Fasching, P.A., Hein, A., Burghaus, S., et al. (2015). Shared genetics underlying epidemiological association between endometriosis and ovarian cancer. Hum Mol Genet 24, 5955-5964.

Luong, H.T., Painter, J.N., Shakhbazov, K., Chapman, B., Henders, A.K., Powell, J.E., Nyholt, D.R., and Montgomery, G.W. (2013). Fine mapping of variants associated with endometriosis in the WNT4 region on chromosome 1p36. Int J Mol Epidemiol Genet 4, 193206.

Mangelsdorf, D.J., Thummel, C., Beato, M., Herrlich, P., Schutz, G., Umesono, K., Blumberg, B., Kastner, P., Mark, M., Chambon, P., et al. (1995). The nuclear receptor superfamily: the second decade. Cell 83, 835-839.

Marla, S., Mortlock, S., Houshdaran, S., Fung, J., McKinnon, B., Holdsworth-Carson, S.J., Girling, J.E., Rogers, P.A.W., Giudice, L.C., and Montgomery, G.W. (2021). Genetic risk factors for endometriosis near estrogen receptor 1 and coexpression of genes in this region in endometrium. Mol Hum Reprod 27.

Masuda, T., Low, S.K., Akiyama, M., Hirata, M., Ueda, Y., Matsuda, K., Kimura, T., Murakami, Y., Kubo, M., Kamatani, Y., et al. (2020). GWAS of five gynecologic diseases and cross-trait analysis in Japanese. Eur J Hum Genet 28, 95-107.

Matalliotaki, C., Matalliotakis, M., Rahmioglu, N., Mavromatidis, G., Matalliotakis, I., Koumantakis, G., Zondervan, K., Spandidos, D.A., Goulielmos, G.N., and Zervou, M.I. (2019). Role of FN1 and GREB1 gene polymorphisms in endometriosis. Mol Med Rep 20, 111-116. McGrath, I.M., Mortlock, S., and Montgomery, G.W. (2021). Genetic Regulation of Physiological Reproductive Lifespan and Female Fertility. Int J Mol Sci 22.

Meuleman, C., Vandenabeele, B., Fieuws, S., Spiessens, C., Timmerman, D., and D'Hooghe, T. (2009). High prevalence of endometriosis in infertile women with normal ovulation and normospermic partners. Fertil Steril 92, 68-74.

Missmer, S.A., Tu, F.F., Agarwal, S.K., Chapron, C., Soliman, A.M., Chiuve, S., Eichner, S., Flores-Caldera, I., Horne, A.W., Kimball, A.B., et al. (2021). Impact of Endometriosis on LifeCourse Potential: A Narrative Review. Int J Gen Med 14, 9-25.

Montgomery, G.W., Mortlock, S., and Giudice, L.C. (2020). Should Genetics Now Be Considered the Pre-eminent Etiologic Factor in Endometriosis? J Minim Invasive Gynecol 27, 280-286. 
Moustafa, S., Burn, M., Mamillapalli, R., Nematian, S., Flores, V., and Taylor, H.S. (2020). Accurate diagnosis of endometriosis using serum microRNAs. Am J Obstet Gynecol. Muller, P.A., Schneeberger, M., Matheis, F., Wang, P., Kerner, Z., llanges, A., Pellegrino, K., Del Marmol, J., Castro, T.B.R., Furuichi, M., et al. (2020). Microbiota modulate sympathetic neurons via a gut-brain circuit. Nature 583, 441-446.

Nothnick, W.B., Swan, K., Flyckt, R., Falcone, T., and Graham, A. (2019). Human endometriotic lesion expression of the miR-144-3p/miR-451a cluster, its correlation with markers of cell survival and origin of lesion content. Sci Rep 9, 8823.

Nyholt, D.R., Gillespie, N.G., Merikangas, K.R., Treloar, S.A., Martin, N.G., and Montgomery, G.W. (2009). Common genetic influences underlie comorbidity of migraine and endometriosis. Genet Epidemiol 33, 105-113.

Nyholt, D.R., Low, S.K., Anderson, C.A., Painter, J.N., Uno, S., Morris, A.P., MacGregor, S., Gordon, S.D., Henders, A.K., Martin, N.G., et al. (2012). Genome-wide association metaanalysis identifies new endometriosis risk loci. Nat Genet 44, 1355-1359.

Pagliardini, L., Gentilini, D., Sanchez, A.M., Candiani, M., Vigano, P., and Di Blasio, A.M. (2015). Replication and meta-analysis of previous genome-wide association studies confirm vezatin as the locus with the strongest evidence for association with endometriosis. Hum Reprod 30, 987-993.

Painter, J.N., Anderson, C.A., Nyholt, D.R., Macgregor, S., Lin, J., Lee, S.H., Lambert, A., Zhao, Z.Z., Roseman, F., Guo, Q., et al. (2011a). Genome-wide association study identifies a locus at 7p15.2 associated with endometriosis. Nat Genet 43, 51-54.

Painter, J.N., Nyholt, D.R., Krause, L., Zhao, Z.Z., Chapman, B., Zhang, C., Medland, S., Martin, N.G., Kennedy, S., Treloar, S., et al. (2014). Common variants in the CYP2C19 gene are associated with susceptibility to endometriosis. Fertil Steril 102, 496-502 e495.

Painter, J.N., Nyholt, D.R., Morris, A., Zhao, Z.Z., Henders, A.K., Lambert, A., Wallace, L., Martin, N.G., Kennedy, S.H., Treloar, S.A., et al. (2011b). High-density fine-mapping of a chromosome 10q26 linkage peak suggests association between endometriosis and variants close to CYP2C19. Fertil Steril 95, 2236-2240.

Painter, J.N., O'Mara, T.A., Morris, A.P., Cheng, T.H.T., Gorman, M., Martin, L., Hodson, S., Jones, A., Martin, N.G., Gordon, S., et al. (2018). Genetic overlap between endometriosis and endometrial cancer: evidence from cross-disease genetic correlation and GWAS metaanalyses. Cancer Med 7, 1978-1987.

Ponomarenko, I., Reshetnikov, E., Polonikov, A., Verzilina, I., Sorokina, I., Elgaeva, E.E., Tsepilov, Y.A., Yermachenko, A., Dvornyk, V., and Churnosov, M. (2020a). Candidate genes for age at menarche are associated with endometriosis. Reprod Biomed Online 41, 943-956. Ponomarenko, I., Reshetnikov, E., Polonikov, A., Verzilina, I., Sorokina, I., Yermachenko, A., Dvornyk, V., and Churnosov, M. (2020b). Candidate Genes for Age at Menarche Are Associated With Uterine Leiomyoma. Front Genet 11, 512940.

Powell, J.E., Fung, J.N., Shakhbazov, K., Sapkota, Y., Cloonan, N., Hemani, G., Hillman, K.M., Kaufmann, S., Luong, H.T., Bowdler, L., et al. (2016). Endometriosis risk alleles at 1p36.12 act through inverse regulation of CDC42 and LINC00339. Hum Mol Genet 25, 5046-5058.

Rahmioglu, N., Macgregor, S., Drong, A.W., Hedman, A.K., Harris, H.R., Randall, J.C., Prokopenko, I., International Endogene Consortium, T.G.C., Nyholt, D.R., Morris, A.P., et al. (2015). Genome-wide enrichment analysis between endometriosis and obesity-related traits reveals novel susceptibility loci. Hum Mol Genet 24, 1185-1199. 
Rahmioglu, N., Nyholt, D.R., Morris, A.P., Missmer, S.A., Montgomery, G.W., and Zondervan, K.T. (2014). Genetic variants underlying risk of endometriosis: insights from meta-analysis of eight genome-wide association and replication datasets. Hum Reprod Update 20, 702-716. Reis, F.M., Coutinho, L.M., Vannuccini, S., Batteux, F., Chapron, C., and Petraglia, F. (2020). Progesterone receptor ligands for the treatment of endometriosis: the mechanisms behind therapeutic success and failure. Hum Reprod Update 26, 565-585.

Rizner, T.L. (2009). Estrogen metabolism and action in endometriosis. Mol Cell Endocrinol 307, 8-18.

Rizner, T.L. (2014). Noninvasive biomarkers of endometriosis: myth or reality? Expert Rev Mol Diagn 14, 365-385.

Sapkota, Y., Attia, J., Gordon, S.D., Henders, A.K., Holliday, E.G., Rahmioglu, N., MacGregor, S., Martin, N.G., McEvoy, M., Morris, A.P., et al. (2015a). Genetic burden associated with varying degrees of disease severity in endometriosis. Mol Hum Reprod 21, 594-602.

Sapkota, Y., Low, S.K., Attia, J., Gordon, S.D., Henders, A.K., Holliday, E.G., MacGregor, S., Martin, N.G., McEvoy, M., Morris, A.P., et al. (2015b). Association between endometriosis and the interleukin 1A (IL1A) locus. Hum Reprod 30, 239-248.

Sapkota, Y., Steinthorsdottir, V., Morris, A.P., Fassbender, A., Rahmioglu, N., De Vivo, I., Buring, J.E., Zhang, F., Edwards, T.L., Jones, S., et al. (2017). Meta-analysis identifies five novel loci associated with endometriosis highlighting key genes involved in hormone metabolism. Nat Commun 8, 15539.

Saunders, P.T.K., and Horne, A.W. (2021). Endometriosis: Etiology, pathobiology, and therapeutic prospects. Cell 184, 2807-2824.

Shafrir, A.L., Farland, L.V., Shah, D.K., Harris, H.R., Kvaskoff, M., Zondervan, K., and Missmer, S.A. (2018). Risk for and consequences of endometriosis: A critical epidemiologic review. Best Pract Res Clin Obstet Gynaecol 51, 1-15.

Spector, A.A. (2009). Arachidonic acid cytochrome P450 epoxygenase pathway. J Lipid Res 50 Suppl, S52-56.

Stark, O., Peckham, C.S., and Moynihan, C. (1989). Weight and age at menarche. Arch Dis Child 64, 383-387.

Stejskalova, A., Fincke, V., Nowak, M., Schmidt, Y., Borrmann, K., von Wahlde, M.K., Schafer, S.D., Kiesel, L., Greve, B., and Gotte, M. (2021). Collagen I triggers directional migration, invasion and matrix remodeling of stroma cells in a 3D spheroid model of endometriosis. Sci Rep 11, 4115.

Tan, H.Y., Ho, V.W., Chan, Y.T., Zhang, C., Wang, N., Xia, W., and Feng, Y. (2020). Combination of Gentiana rhodantha and Gerbera anandria in the BL02 formula as therapeutics to non-small cell lung carcinoma acting via Rap1/cdc42 signaling: A transcriptomics/ bio-informatics biological validation approach. Pharmacol Res 155, 104415. Taylor, H.S. (2000). The role of HOX genes in the development and function of the female reproductive tract. Semin Reprod Med 18, 81-89.

Treloar, S.A., O'Connor, D.T., O'Connor, V.M., and Martin, N.G. (1999). Genetic influences on endometriosis in an Australian twin sample. sueT@qimr.edu.au. Fertil Steril 71, 701-710. Treloar, S.A., Wicks, J., Nyholt, D.R., Montgomery, G.W., Bahlo, M., Smith, V., Dawson, G., Mackay, I.J., Weeks, D.E., Bennett, S.T., et al. (2005a). Genomewide linkage study in 1,176 affected sister pair families identifies a significant susceptibility locus for endometriosis on chromosome 10q26. Am J Hum Genet 77, 365-376. 
Treloar, S.A., Zhao, Z.Z., Armitage, T., Duffy, D.L., Wicks, J., O'Connor, D.T., Martin, N.G., and Montgomery, G.W. (2005b). Association between polymorphisms in the progesterone receptor gene and endometriosis. Mol Hum Reprod 11, 641-647.

Tulac, S., Nayak, N.R., Kao, L.C., Van Waes, M., Huang, J., Lobo, S., Germeyer, A., Lessey, B.A., Taylor, R.N., Suchanek, E., et al. (2003). Identification, characterization, and regulation of the canonical Wnt signaling pathway in human endometrium. J Clin Endocrinol Metab 88, 3860-3866.

Uimari, O., Rahmioglu, N., Nyholt, D.R., Vincent, K., Missmer, S.A., Becker, C., Morris, A.P., Montgomery, G.W., and Zondervan, K.T. (2017). Genome-wide genetic analyses highlight mitogen-activated protein kinase (MAPK) signaling in the pathogenesis of endometriosis. Hum Reprod 32, 780-793.

Ulrich, D., Tan, K.S., Deane, J., Schwab, K., Cheong, A., Rosamilia, A., and Gargett, C.E. (2014). Mesenchymal stem/stromal cells in post-menopausal endometrium. Hum Reprod 29, 1895-1905.

Vashisht, A., Alali, Z., and Nothnick, W.B. (2020). Deciphering the Role of miRNAs in Endometriosis Pathophysiology Using Experimental Endometriosis Mouse Models. Adv Anat Embryol Cell Biol 232, 79-97.

Vercellini, P., Fedele, L., Aimi, G., Pietropaolo, G., Consonni, D., and Crosignani, P.G. (2007). Association between endometriosis stage, lesion type, patient characteristics and severity of pelvic pain symptoms: a multivariate analysis of over 1000 patients. Hum Reprod 22, 266271.

Wang, H., Critchley, H.O., Kelly, R.W., Shen, D., and Baird, D.T. (1998). Progesterone receptor subtype $B$ is differentially regulated in human endometrial stroma. Mol Hum Reprod 4, 407-412.

Wang, W., Li, Y., Li, S., Wu, Z., Yuan, M., Wang, T., and Wang, S. (2017). Pooling-Based Genome-Wide Association Study Identifies Risk Loci in the Pathogenesis of Ovarian Endometrioma in Chinese Han Women. Reprod Sci 24, 400-406.

Wang, Y., Hu, S., Yao, G., and Sun, Y. (2021). Identification of HOXA10 target genes in human endometrial stromal cells by RNA-seq analysis. Acta Biochim Biophys Sin (Shanghai) 53, 365371.

Wang, Z., Yosida, S., Negoro, K., Kennedy, S., Barlow, D., and Maruo, T. (2004). Polymorphisms in the estrogen receptor beta gene but not the estrogen receptor alpha gene affect the risk of developing endometriosis in a Japanese population. Fertil Steril 81, 1650-1656.

Winuthayanon, W., Hewitt, S.C., Orvis, G.D., Behringer, R.R., and Korach, K.S. (2010). Uterine epithelial estrogen receptor $\{$ alpha\} is dispensable for proliferation but essential for complete biological and biochemical responses. Proc Natl Acad Sci U S A 107, 19272-19277. Winuthayanon, W., Lierz, S.L., Delarosa, K.C., Sampels, S.R., Donoghue, L.J., Hewitt, S.C., and Korach, K.S. (2017). Juxtacrine Activity of Estrogen Receptor alpha in Uterine Stromal Cells is Necessary for Estrogen-Induced Epithelial Cell Proliferation. Sci Rep 7, 8377.

Xue, Q., Lin, Z., Cheng, Y.H., Huang, C.C., Marsh, E., Yin, P., Milad, M.P., Confino, E., Reierstad, S., Innes, J., et al. (2007a). Promoter methylation regulates estrogen receptor 2 in human endometrium and endometriosis. Biol Reprod 77, 681-687.

Xue, Q., Lin, Z., Yin, P., Milad, M.P., Cheng, Y.H., Confino, E., Reierstad, S., and Bulun, S.E. (2007b). Transcriptional activation of steroidogenic factor- 1 by hypomethylation of the 5 ' CpG island in endometriosis. J Clin Endocrinol Metab 92, 3261-3267. 
Yang, M.H., Wang, P.H., Wang, S.J., Sun, W.Z., Oyang, Y.J., and Fuh, J.L. (2012). Women with endometriosis are more likely to suffer from migraines: a population-based study. PLoS One 7, e33941.

Yilmaz, B.D., and Bulun, S.E. (2019). Endometriosis and nuclear receptors. Hum Reprod Update 25, 473-485.

Yotova, I.Y., Quan, P., Leditznig, N., Beer, U., Wenzl, R., and Tschugguel, W. (2011).

Abnormal activation of Ras/Raf/MAPK and RhoA/ROCKII signalling pathways in eutopic endometrial stromal cells of patients with endometriosis. Hum Reprod 26, 885-897.

Yovich, J.L., Rowlands, P.K., Lingham, S., Sillender, M., and Srinivasan, S. (2020). Pathogenesis of endometriosis: Look no further than John Sampson. Reprod Biomed Online 40, 7-11.

Zhao, Z.Z., Nyholt, D.R., Thomas, S., Treloar, S.A., and Montgomery, G.W. (2008).

Polymorphisms in the vascular endothelial growth factor gene and the risk of familial endometriosis. Mol Hum Reprod 14, 531-538.

Zondervan, K.T., Becker, C.M., and Missmer, S.A. (2020). Endometriosis. N Engl J Med 382, 1244-1256.

Zondervan, K.T., Rahmioglu, N., Morris, A.P., Nyholt, D.R., Montgomery, G.W., Becker, C.M., and Missmer, S.A. (2016). Beyond Endometriosis Genome-Wide Association Study: From Genomics to Phenomics to the Patient. Semin Reprod Med 34, 242-254. 